\title{
The Relationship between Target Costing and Competitive Advantage of Jordanian Private Universities
}

\author{
Waleed Mjalli Al-Awawdeh \\ Department of Business Administration, Faculty of Business and Finance \\ Al al-Bayt University, Jordan \\ E-mail: walawawdeh@yahoo.com
}

Jamal Adel Al-Sharairi

Department of Accounting, Faculty of Business and Finance

Al al-Bayt University, Jordan

E-mail: jamalsharairi@yahoo.com

Received: November 29, 2011

Accepted: February 14, 2012

Published: April 16, 2012

doi:10.5539/ijbm.v7n8p123

URL: http://dx.doi.org/10.5539/ijbm.v7n8p123

\begin{abstract}
The study explored the relationship between target costing and competitiveness at Jordanian Private Universities. The research question regarding target costing focused on leadership of target selling price, customer needs, degree of developing a team work, cost of the product life cycle, stage of product design and value chain development. A questionnaire was used to elicit data. Two scales were used to measure the estimates by financial managers, directors of planning and quality, and heads of accounting departments in the universities. The sample size was 50 subjects, and response rate was $80 \%$. Findings of the study indicated that: universities have a medium target costing dimensions of (3.48); the dimension of target selling price leadership was the highest and reducing the life cycle of university specialization was the lowest; universities enjoy a medium competitive advantages with a score of (3.46); and expansion in specializations was the highest in performance and university's specializations cost was the weakest. Results showed a significant difference in the strength of links between the dimensions of the target costing technique and the dimensions of strengthening the competitive advantage.
\end{abstract}

Recommendations suggested that universities in general and Jordanian Private Universities in particular, have to activate the dimensions of target costing technique to achieve the competitive advantages and promote it.

Keywords: Target costing, Competitive advantage, Higher education, Private University, Jordan

\section{Introduction}

World economic transformations created tremendous opportunities and significant challenges to companies. Accordingly, competitive advantages interested large number of researchers, where some considered target costing as a strategic goal of business organizations, where its construction and promotion requires companies to adopt target costing technique Ewert and Emst, (1999). It is applied in many Japanese companies, where the Japanese industry developed some of the American methods and concepts, earned new properties correspond with the business environment variables facing this industry. The experts of Japanese industry developed the American so-called Value Engineering, and transferred it to the dynamic system to reduce the cost and planning profit, while ensuring quality and achieving competitive advantages. More than $80 \%$ of the industries in Japan, such as automobiles, electronics, machine tools and dyeing, use target costing technique Ansari and Bell, (1997).

Fierce competition of Jordanian and Arab companies with the Global market, led to the withdrawal of some from the market, and forced others to apply modern methods of costs. Conventional cost systems are no longer sufficient to identify opportunities for corporate success and survival, without the use of new technologies in management of costs. Conventional costs cannot respond to environmental factors (economic, social, technological, political and legal) and do not have the ability to achieve cost control and substantial reduction in cost Ansari et al., (2006); Cooper and Slagmulder, (2002); Cooper and Chew, (1996). On the other hand, 
Jordanian Private Universities adopted target costing technique and its application as a technology that may support competitive advantages and achieve a significant reduction in costs both in the design phase of products or in early follow up Ibusuki and Kaminiski, (2007).

The importance of the study stems from the role that target costing technique can play in the promotion of competitive advantages, at a time when the target costing became one of the most important techniques of cost management used by Jordanian Private Universities in response to competition with other universities, customers' needs, and constraints of the external environment. The research will contribute to the activation of outcomes that result from the use of target costing technique in order to enhance competition.

\section{Related Literature Review and studies}

\subsection{Target Costing}

Nowadays, competitive and technological progress become critical for both manufacturing and services industries as a result of products life shortage and changing in customers' needs. This requires organizations to stimulate a suitable business operation to achieve their targeted growth and adopt suitable price policies.

Pricing on the basis of studying and analyzing the market is more recent because it is based originally on the basis of market's researches to determine the price and then the cost in the light of that price is determined after a specified margin profit that the organization desires Zeenat, (1995). The basic idea of target costing system is considered a simple and direct idea. Target costing system refers plan for a low cost for new products and provide products to the market with high quality and competitive price for customers in order to achieve a reasonable profit. This can be achieved through reducing stages of the cost of productive factors through product life cycle stages in a product planning stage, and design, development. However, the process of preparing targeting cost is characterized by complexity and multi-faceted, so it is useful to recall the different points of view to illustrate the concept of the target costing. Al-Thahabi and Al-Ghabban (2007) used the concept of target costing in general to indicate that cost-management techniques oriented to the market as they are used in presenting the product stage from the product life cycle in order to enhance profitability and productivity. Al-Suboo (2000: 44) defined the cost target technique as one of the cost management tools in a competitive environment because it targets three main competitive elements which are: price, quality, and cost, as well as creativity. Mufti and Sheikh (2005) defined it as one of management accounting introductions that is used in cost management to reduce the costs of the product's design and its development and provide a variety of high quality products that satisfy customer needs and desires. Ewert and Emst (1999) described it as a strategic approach for accounting management used in the management of product cost. While Cooper and Slagmuder (2002) described it as an accounting method for future profits of company's management by including the target costing clearly in the process of product development. Further, Fouda (2007) and Abdel-Al-Dayem (2001) considered target costing as a strategic entry point in a modern manufacturing environment. It helps the company in planning a low cost for new products and provide products to the market with high quality and competitive price for customers in order to achieve a reasonable profit by reducing the stages of the cost of productive factors through product life cycle stages in a product planning stage, design, development, and selling. In comparison with the traditional cost accounting the focus of organizations were more oriented toward producing the products and then determine the cost. Then organizations would try to recover their cost with a percentage of profit by selling products in markets (Ansari, et al, 2006).

The application of target cost technique in various organizations designed to achieve the following objectives Al-Matarneh, (2008); Cooper and Slagmuder, (2002); Robinson, (1999); Lee, (1994):

1) Contribute in achieving satisfactory profit margin for the company, a competitor sale price for its production's units to ensure and achieve its strategic objectives.

2) Provide competing product in terms of specifications and required quality, price, time and meet the needs of beneficiaries and their wishes within their financial potential.

3) Monitor stages of product life cycle, and after-sales service.

4) Reduce the costs of production elements for the product to ensure and achieve target profit.

5) Achieve the objectives of company's management over the long term.

The conventional approaches of cost management is not compatible with the updated industrial and service environment, because they are trying to control cost and quality after the completion of producing the product, accessing to the point of a temporarily balance, and focusing on the internal environment of the organization. In addition it solves the obstacles in a cumulative view and not with an overview, as the target costing is more 
appropriate to meet the needs of the service and contemporary industrial environment that achieve the integration of three main dimensions of the competitive advantage: quality, cost and time, as companies seek to provide products for the current conditions of the industry and demand conditions and market conditions through this strategic entry Ansari et al., (2006).

\section{2 dimensions of Target Costing}

Ansari et al. (2006) developed a model in which target costing depends on achieving appropriate profit through planning, analyzing and studying both profitability and cost at the same time. It includes six main principles:

1) Leadership of Target Selling Price

Competitive price is usually subjected to the competition conditions, supply and demand conditions and other factors controlling the market. The target profit is determined by the financial requirements of the organization and conditions of the industry which belongs to the company. It concludes that the elements controlling in determining the maximum limit of the cost which is located in the external environment of the company under the target costing technique, on the contrary, the conventional system, which depends mainly on the production factors within its internal environment, this principle consists of two sub-principles.

\section{2) Focusing on Customer}

It is necessary to identify what the customer needs, and what the competitive organizations are doing now, and what is expected to do in the future to meet the needs of customers. A focus on customers led to streamline and guide the engineering activities to develop and build products, where market's demands and needs identified and forming engineering requirements. The product characteristics will not be verified unless meeting customers' expectations or at least be compatible with it or exceed it. The customer must have the willingness to pay for these properties and improvements.

\section{3) Using and Developing a Team Work}

Target costing technique is based on the use a team work for each of the product and operation. Team work consists of members with expertise of different specialties and functions made up of; design engineer, manufacturing engineers, a representative from each of the production, sales and marketing, procurement, accounting and services after-sales functions, the staff also includes representatives from outside the entity such as the member for suppliers and another for customers, distributors and wholesalers and retailers and the materials used and shipping companies and transport. This team is responsible for all phases of product life cycle in the broad sense. Based on this, it is noted that the team work is not just a multi-talented people who contribute their expertise and capabilities, but also members who are fully responsible for the product in all stages of its life cycle.

\section{4) Reduce the Cost of the Product Life Cycle}

Target costing technique is based on studying all elements of costs related to possessing the product through all stages of its life cycle. These items include the purchase price, operating costs, operating requirements, costs of maintenance and repair in addition to the costs of disposal of the product at the end of its life cycle. The target costing system aims at doing so to reduce the cost of the life cycle of the product.

\section{5) Focus on the Stage of Product Design}

Target costing technique relies on the operations of product design and designing production processes, which constitute a key element in cost management. Therefore, it focuses on the design phase, and reduces time to put the product on the market, with the exclusion of prior expensive variables and changes, which may deplete a lot of time and effort if they are not disposed of early. This happened because of the late discovery of these variables and unwanted deviations in the late periods of the life cycle of the product which may result a high costs that is difficult to control.

\section{6) Attention to all Stages of the Value Chain}

Target costing system is based on involving representatives of all the value chain such as suppliers, agents, distributors and existing after-sales service in the target costing system. This aim to spread concepts and efforts to reduce the cost over all the value chain through the development of the spirit cooperation and understanding among all members of organizations associated with the product from suppliers, producers, customers, agents and service providers. The target costing system is based on the concept of long-term relations and mutual benefits in the long term between suppliers and all members of representatives of all the value chain. 


\section{3 dimensions of Competitive Advantage}

Liu (2003) stresses on that the company's competitive advantage means the company advantage from the perspective of market of the product that will bring more competitive position for it. While Stevenson (2007) stresses on that it is practically aims at meeting customer's needs and desires in order to possess the company's products. Evans and Collier (2007) indicated that it is the announcement of company's ability to excel in the fields of marketing and financial management are above all its priority by the ability of the company's senior management to identify customer's needs and desires. He showed how to deliver it to them at the right time, in addition to taken into account the rate of the operational capacity of the company.

Also a competitive advantage is seen in general, as being the use of the organization for the internal strengths points of its administrative and functional performance, so it can achieve a feature that the competitors cannot emulate or imitate Pitts and David, (1999). The company has a sustainable competitive advantage when it can be able to maintain the rate of profit higher than the rate of profitability of the industry for several years through its ability to produce its products at lower costs than its competitors Hill and Jones, (2008). This is from one hand; and from the other hand, the target costing considered as the technical support of the organization's activities in addition to its assistance in access what is the best by providing senior management with the necessary information to manage costs, because they represent a comprehensive system of planning profit, and works to reduce production costs Abdel-El-Dayem, (2001).

After reviewing the literature of the study, it is noted that (Porter's) model can be applied, which developed by (Wiseman's) and he called it, the strong strategic momentum theory, which is useful in the competitive environment to be a more comprehensive framework, he selected the competitive moves of the organization in five competitive advantages, adopted by the present research as dimensions for competitive advantage Zoubi, (2005, PP: 161-162):

- Differentiation and Quality of the Products: Adding unique characteristics for the organization's products will give more competitive attraction in the target market, they are essential to the success of organizations, and to achieve better competitive position Darwish, (2007). Due to the importance of excellence and quality, two different trends have emerged for their define: from the view of the organization; means corresponding to predetermined specifications, Customer's perspective; means the level of organization's service and how to achieve the price that customers want to pay to obtain the product or have it. Krajewski and Ritzman, (1999) explain that there are two competitive advantages treated with quality, which are the quality of design and quality of matching. Based on the foregoing, the two researchers see that the quality refers to a set of features and specifications that the product owned which gives it the competitive attractiveness of other products and be benefited to customers.

- The Cost of Products: The cost of production defined as being the value of what companies pay to get the input of various production, such as: costs of information, raw materials and labor force; the costs take two forms: Alternative Costs, they mean the value of alternative goods paid by the organization, which can be produced with the same resources used for the production of present goods, with the use of these resources in the best alternative usage; and private costs for present goods, divided into two parts: the Apparent Cost, and Implicit Costs Al-Qura'an, (2007).

- Based on the above, the two researchers see that reducing costs for private universities can be done through: research and development costs, marketing, the costs of administrative and teaching faculty, students, administrative buildings and laboratories.

- Innovation: Innovation takes many forms harmonize with outputs that come with the creative process, namely Al-Skarna, (2005):

- Innovation means any differentiation comes up with what is different from direct competitors and other, creates a sample of the market by unique responding to its needs through the creativity.

- Innovation; come up with new wholly or partly in exchange for the existing situation, as a source of renewal in order to maintain company's market share and its development.

- Innovation; new combination which is like putting old things in a new synthesis in the same field (combination of things) or move it to another place not used before.

- Growth: Means the expansion to achieve the level of goals exceeding what has been achieved in previous years, this is done by increasing profitability, or increases the amount of revenue from sales, or increase market share, or market expansion. This can be achieved through increase in the volume of domestic sales by encouraging domestic demand in action to reduce the prices or use well-known brands and increase the volume 
of export sales, also they determined on the other hand with the number of competitors, where the small countries' companies such as Jordanian companies pushed more to search for foreign markets to increase market share, an increase of share sales of the organization for the sales competitors' organizations Ergun and Yilmaz, (2008).

- Alliances: Global strategic alliances known as forming a strategic alliance between the two organizations with their skills and capabilities to achieve the goals and objectives of the strategy, which a single organization cannot achieve alone Wahyuni et al., (2007). The objectives of alliances between companies are to invade new markets, knowledge participation, participate in the risk, reduce costs, and reduce competition Hill and Jones, (2008).

\subsection{Related Studies}

Al-Matarneh (2008) indicated that Jordanian industrial companies do not implement target costing and that these companies have the necessary elements to apply it, that there are a number of obstacles prevent its application such as fear of adopting new methods. Mufti and Sheikh (2005) concluded that the most important goals pursued by organizations in applying target costing is to reduce cost and increase its competitiveness, and that the most sections applying this technique is the accounting, design and production departments, also that there are a few companies apply this technique because of lack of knowledge of this technology. While Abdel-Dayem (2001) indicated that the target costing uses the available information to costs management in the early stages of product life cycle; enabling the company to achieve the target costing without sacrificing the wishes of customers, and maintain the quality of the products will achieve competitive advantage, providing the product to market in time, also the style value engineering contributed to increase cost-effectiveness. Zeenat (1995) assured that the method of target costing is good for the application efficiently in the case of pricing of new products, especially if the company does not enjoy great freedom in controlling the price, as the study explained that the success of the application of this method is significant in the maquiladora industries. Arab library lacks of studies that deal with subjects' link between target costing technique (TC), and the competitive advantage, particularly field studies, as one of the modern technology in an environment of modern services that meet an effective management costs.

Ibusuki and Kaminiski (2007) indicated that relying on target costing technique, and the value engineering method in the management costs of the company were successful, where it leads to reduce product cost, and achieve quality and specifications that suit customer needs, and strategies of the company. Ellram (2006) specified that the purchase of raw materials affect positively in achieving the target costing. Cooper and Chew (1996) determined that the process of reducing costs using the method of target costing is an integrated process done by an integrated team of members of the company through the re-design of the product, provided that it does not affect the functional efficiency of the product. Kato and Chow (1995) reached that the most Japanese companies that have applied a target costing focused on applying the concepts of profitability management, considering that the target costing method is consistent with other administrative systems applied within the company. Fisher (1995) established that the primary objective of the application of target costing is to reduce overall costs without compromising the characteristics of product quality, and using the cost accounting activity method is a key element when applying the target costing method, so we get more accurate costs for the product. Also, Monden (1995) reached that the lack of an appropriate method of conventional standard costs methods for the purposes of costs' control in a modern competitive business environment, as referred to the success of the target costing method, which depends on market trends, and provides a bridge between the strategic marketing and operational control, as well as the possibility of using different methods to achieve the target costing such as reducing the number of defective parts and reduce the cost of tools and equipment and using the re-engineering method. Further, Kato (1993) reached that the target costing method is not working in isolation within the company, but there are ways to help to support the application of the method within the company, such as value engineering, value chain analysis and developed costs.

From the above review, the following is noticed:

Some studies considered that the target costing technique is an integrated system with other systems and methods, also it works within the company as (A.B.C), and applying a standard cost is not a substitute for applying the target costing method.

- Most studies focused on planning and design of products and did not give adequate attention to study costs or the information supported the activities and marketing researches, which is the first step for applying targets cost technique.

- The application of this technique does not have a single goal, but a set of goals, the most important is to reduce costs in the process of planning and product design, followed by emphasizing on quality and to achieve 
timely delivery of products to both new and improved.

- There is a lack of interest in the studies on theoretical and practical aspects to the entry of target costing and its various applications, which carries the pricing of products.

- Some previous studies considered that the essential aim target costing technique is to reduce the cost of the product in the two phases of design and product development, while considering the target costing technique from this narrow-angle only is minor, while the technique is considered more comprehensive than that and it not limited to the two phases of design and product development, but it is a continuing method to reduce costs throughout the product life cycle, taking into account the improvement of product quality.

\section{Statement of the problem}

The study tries to link target costing technique to competitive advantages and strengths at the level of Jordanian Private Universities, especially those that attract students from the international market. The concept of target costing technique is relatively recent at educational institutions. Many educational institutions still do not show enough attention to target costing technique; they are unwilling to venture in modern services for reasons related to inability to control markets and pricing decisions and costs. Whilst, competitive environment affect cost accounting which is represented by updates of cost management as target costing technique, through which it becomes possible to reduce costs. This study is the first of its kind, which looks at the nature of the relationship between components of target costing technique and competitive advantages of Jordanian Private Universities as a model. It refers to the dimensions and components of the competitive advantages in the form of Porter developed by Wiseman, as he called it strategic driving force theory, which is developed to comprehensiveness framework.

\section{Research Objective}

The main objective of the study is to identify the extent to which Jordanian Private Universities use target costing technique and the dimensions of competitive advantages. Further the study will try to identify the most important dimensions that target costing technique is based on in building and strengthening the competitive advantages of Jordanian Private Universities.

The research will answer the following two questions:

1) what is the estimation level of implemented cost targeting dimensions in the Jordanian private universities according to functional managers?

2) what is the estimation level of implemented dimensions that form the competitive advantages in the Jordanian Private Universities according to functional managers?

\section{Research Hypotheses}

1) There is no relationship between target costing technique dimensions and the dimensions of the competitive advantages.

2) The dimensions upon which cost target technique based on have no predictive ability of the competitive advantages of the universities.

\section{Research methodology}

The study used descriptive analytical method of secondary and primary data. Based on previous studies and theoretical review, a tool was developed to determine the dimensions that form the target costing technique measurement and competitive advantage. It also depend on statistical analysis as an account of reliability coefficient, (Cronbach's Alpha), which gives the highest stability and (Hewitt) method that gives less stability in addition to correlation coefficients, descriptive statistics, arithmetic means, and standard deviations for each of the components of cost target technique, and the dimensions of competitive advantage.

\subsection{Population and Sample of the study}

The study population included Jordanian Private Universities which are (13) University. A list of the names of these universities has obtained from the website of the Ministry of Higher Education and Scientific Research. The sample was selected from the officials of the financial departments units, who are responsible to determine its target costing and how to use them in strengthen the desired competitive advantages. The selection of these universities is for: (1) the importance of target costing technique for it; and (2) the availability of their subjective data noting that the activity of these profitable universities may extend to the Arab and international markets, in addition to the local market. About 50 Questionnaires were distributed, and 40 questionnaires were received back. 


\subsection{Study Design and Questionnaire}

In order to answer the research questions the following variables have been measured: (1) target costing variable, six dimensions were included in the questionnaires (the leadership of target selling price, focusing on the students, using work teams and their development, reducing the cost of the life cycle of university specialization, focusing on the design phase of university specialization and taking care of all stages of the value chain); (2) assessments of strengthening competitive advantage, five dimensions were questioned (Excellence and Quality of University Specializations, University Specialization Cost, Innovation and Creativity in Academic Specialization, Expansion of Academic Specializations, and Alliance).

The questionnaire was developed based on Rankin, Knezek, Wallace, and Zhang (2004). Moreover, questionnaire were revised and tested regarding triangulation and validity.

\subsection{Test Reliability and analysis of the coefficient of internal consistency}

Table 1 shows results of the statistical indicators of the credibility and consistency of the questionnaire. Reliability coefficient was calculated in a Cronbach's way which indicated a high stability of estimator. Hewitt method was also implied and the results were relatively high. Values of transactions consistency (Cronbach's alpha) for the study areas ranged between $(0.70-0.80)$, all values were acceptable for the application of the study purposes. Hewitt's transactions for study field ranged between (50.26-152.86), which are acceptable values for the application of the study purposes.

\section{Insert Table 1- here}

A factor analysis was conducted using Confirmatory Factor Analysis with orthogonal rotation in a manner of Varimax rotation to measure the degree of saturation of each paragraph of the study on the field that belongs to it.

\section{Insert Table 2- here}

The table illustrates the degree of saturation of the paragraphs of the study. It appears that statements which loaded more than $(0.40)$ are used to measure the variable.

\section{Insert Table 3- here}

The correlation coefficients were calculated to assess the adjusted statistical indicator of affiliation credibility for one paragraph of the measure which is supposed to belong to it are high links, 0.43 is their less.

Corrected coefficients correlation was extracted from each paragraph in the target costing dimensions as table 3 shows. It is noted that all the links with the dimensions of the paragraphs to which they belong is relatively strong.

\subsection{Data Statistical treatment}

Several statistical techniques have been applied in this study such as:

1) Descriptive analysis such as: Averages and standard deviations.

2) Partial Correlation Coefficients and Regression Analysis was used to test the hypothesis.

For the sake of discussion and interpretation of results of the study, the researchers applied on the following equation to compute the range:

Range $=$ (the highest average value- the lowest average value) / (number of levels): $(5-1) /(3)=1.33$

Therefore the results will be as the following:

1) Results between $(1-2.33)$ represent a week average response rate.

2) Results between (2.34 - 3.67) represent a medium average response rate.

3) Results between (3.68 - 5) would be a high average response

\section{Findings presentation and results discussion}

\subsection{Descriptive Analysis}

Insert Table 4- here

Table (4) showed that the proportion of managers in the study sample, who are in the age group of 49-40 years, reached a percentage of $35 \%$, while the percentage of managers in the age group of $39-30$ years is $26 \%$. The percentage of managers in the study sample in both age groups of $29-20$ years and 50 years and more is $24 \%$ and $15 \%$, respectively. As for educational level, Table (4) indicates that $80 \%$ of the participated managers have the 
first university degree (BA), while the managers holding high studies, representing $15 \%$, also Table (4) shows the low percentage of managers who hold the degree of diploma college or less, as they represent $5 \%$, while there was no representation for the Ph.D. holders in the analysis unit. In terms of university specialization (Major), 64\% of the participated managers hold business administration degree. The percentage of managers who hold accounting degree was 33\%, while the percentage of managers from other specialization was $3 \%$. Distribution of respondents according to their experience in the specialization field is presented in Table (4) as follows: $50 \%$ of respondents have experience equivalent to five years or less, and those with experience of (10-6) years are $(30 \%)$, and those whose their experience is more than or equal to $11-15$ years are $15 \%$, while those with experience in their current jobs were 16 years and more make $5 \%$ of the total sample. More than half of them holding the post of financial manager (52\%), percentage of managers who hold the position of director of planning and quality were $28 \%$, while $54 \%$ of the respondents are from the senior management level, and $41 \%$ of the middle management level, as shown in Table (4).

In general, previous percentages can be summarized that the sample's members with an age average and educational level which is relatively high, and with suitable scientific specialization, have the sufficient experience, they are concerned in the use of target costing technique, which gives an indication that the obtained results related to the dimensions of target costing technique and the competitive advantage dimensions were up to the level of professional credibility as they are factors that give credibility to the reality of the universities' work that they work in.

\section{Insert Table 5- here}

\subsection{Answering the Research Questions}

Means and standard deviations of the statements regarding leadership of selling target price as one of the dimensions of target costing technique are presented in Table 5. It is clear from the table that all the statements are high, while the statements for contribution of target costing technique to expand the number of seats in the university in the markets have an average of (4.28). The contribution of target costing technique to increase market share in the different markets in which the university operates have an average of (4.27), to assist the university to determine the target profit in accordance with the financial requirements have an average of (4.18), and to determine the target profit in accordance with the conditions of service of higher education have an average of (4.09). Further, in contributing to expand the number of seats in the university in the markets, according to the conditions of supply and demand and help the university has an average of (4.00).

This supports Ibusuki and Kaminisk (2007); Ellram (2006); and Zeenat, (1995) who stress the importance of Target Costing Technique on pricing of new products, inputs purchasing, lower product cost, and achieving quality for customers these have positive reflecting on the dimensions of competitive advantage of the company's.

\section{Insert Table 6- here}

The estimations revealed the importance of the role that Target Costing Technique plays in focusing on the clients (students), in Table (6). The overall average was (4.08), especially in regards to focusing on achieving excellence on students expectations, or to respond to the renewable needs of students, or respond to students needs in terms of quality of educational services and to meet their expectations. This supports Monden (1995) who indicated that inappropriate standard conventional costs method for the purposes of cost control in competitiveness environment. He indicated that method of target costing is successful, as it depends on market trends that provide a bridge between the strategic marketing and operational control.

\section{Insert Table 7- here}

In terms of using work teams and developing them, the estimations are presented in the Table indicate the important of targets cost technique. One of the most basic dimensions underlying target costing technique is using work teams, because they are banks of information for the university and its promotion. It is clear that the development of a new university specialization through a specialized and experienced work team with varied duties (academic, administrative, financial and technical departments) on competitiveness geographical basis, or through graduates student members involvement, members of the parents, means were between (4.36) and (3.73), followed by the importance of involving members of the labor market in the team with an average of (3.45).

The process of prediction and expectation of future economic trends and movements of competitors are the most important success factors. Therefore, respondents stressed the role target costing technique played by following the formation of work teams, which agrees Ansari et al. (2006), as they indicated that the work team should include representatives from outside the entity. 
Insert Table 8- here

Regarding the decrease in cost of the life cycle of university specialization, the estimations for the sample in the Table (8) indicated a medium approval degree of (2.50-3.49) where their responses came between (2.73) and (3.27), these results indicate lack of sufficient attention in the life cycle of university specialization, where Al-Matarneh (2008), Cooper and Slagmuder (2002), Robinson (1999), Lee (1994) pointed out the need to monitor all stages of product life cycle, after-sales services in order to achieve the objectives in the long term.

\section{Insert Table 9- here}

In terms of focusing on the design phase of university specialization, the table showed that the average was (2.99) despite the role played by target cost technique in relation to this aspect, responses ranged between (2.82) and (3.18). These results indicate lack of sufficient attention in designing university specialization phase, while Fouda (2007) and Abdel-Dayem (2001) consider it as a strategic entry point in the modern working environment that helps in planning low cost for new products, provide products to the market with high quality and competitive price to customers, achieve a reasonable profit by reducing the cost of productive factors, and develop ending with selling it.

\section{Insert Table 10- here}

Finally, taking care of all stages of the value chain, table showed that overall average was (3.08), despite the role played by target cost technique in relation to this aspect, responses ranged between (2.91) and (3.27). This indicates lack of adequate attention in the value chain, contrary to Kato (1993) suggestions.

The five dimensions to enhance the competitive advantage which are: Excellence and Quality of University's Specializations, University Specialization Cost, Innovation and Creativity in Academic Specializations, Expansion of Academic Specialization, and Alliance.

\section{Insert Table 11- here}

Table shows that universities strive continuously by trying to reduce the direct costs or the expenses related to teaching, educational, administrative and financial process, which is really the goal that private universities seek. This will reflect positively on their competitiveness through providing rates of their educational services for students compared to their competitors. In regard to the dimension of Excellence and Quality of University's Specializations, the averages indicted an approval in high degree, especially in regards to the endeavor of universities to make their educational programs' specifications and offered specializations matched with the requirements of the market. This means that universities are keeping pace with students needs.

In regards to University Specialization Cost, responses in Table 11 showed approval in a high degree. In terms of the universities' persuasion to reduce the rate of offering university specializations which are unprofitable, or in term of improving the daily performance average for the faculty members and to improve their ability to use technology, results showed approval in a high degree. For the quickness of universities to launch new specializations, the use of available technology by competitors, and the competitive prices are the most important dimensions of target costing that offer competitive advantages. In terms of Expansion of University's Specializations in the specialization and according to labor market, needs of students, costs, analysis, and speed of accessing to customers, results showed that these are the most important factors of target costing, which help in increasing the number of Arab and foreign students, penetrating new markets, and thus achieving increase in profit and market share. As for Alliance with Arab and international universities, results showed this as the most important dimension of the competitive advantage. It enhances competitiveness of universities and enthusiasm of students to enroll in it. Also the alliance will ease administrative and financial burdens.

\subsection{Testing the first main Null Hypothesis $\mathrm{HO}$}

That states: There is no relationship between the dimensions of the target costing technique and the dimensions of the competitive advantages.

\section{Insert Table 12- here}

Table 12 shows analysis of correlation and multiple regressions for all of the factors in order to determine the overall contribution of these factors. It is clear from the table that there are six groups of factors are all statistically significant. The components dimensions of the technique on one hand, and components dimensions to enhance the competitive advantage are different especially with regard to focusing on the students.

\subsection{Testing the second sub-hypothesis $\mathrm{HO}$}

That states: The dimensions upon which cost target technique based on have no predictive ability of the 
competitive advantages of the universities.

\section{Insert Table 13- here}

The internal correlation within each field are more homogenous, and the introduction of these correlations in the process of other analyzing for predictive purposes. As seen from Table 13, focusing on students as a dimension of target costing is the most predictive capability of competitive advantage as a whole. This is followed by target price leadership, while focus on the design phase of university specialization does not have statistical significant in improvement of the predictive ability of competitive advantages.Findings revealed the importance of the six factors of target costing, where means are: $(4.14,4.08,3.82,3.08,2.99,2.92)$, respectively. Therefore, departments and units in the sampled universities play an important role in guiding employees and motivate them to use target costing technique and up-to-date developments in cost management. Target costing technique is a tool to provide data and information to support decision-making process concerning the adoption of the strategic dimensions of competitive advantages. Where the arithmetic means of these dimensions (Excellence and Quality of University's Specializations, University Specialization Cost, Innovation and Creativity in Academic Specializations, Expansion of Academic Specialization, and Alliance) are respectively (3.62, 3.30, $3.34,3.69,3.56$ ) with an overall average $=3.46$.

Results showed difference in strength and significance statistical level of dimensions within the axes (target costing and enhance the competitive advantage) between medium and high, see Table 12. This means difference of relative factors with the predictive ability of these dimensions. These factors contributed after focusing on students, these are the most statistically significant in overall competitive advantage, as indicated in Table 13.

\section{Summary of Conclusion}

1) The study indicates that the Jordanian Private Universities are adopting target costing with an overall average of (3.48). Findings indicate that private universities enjoy a medium competitive advantages with an average of (3.46);

2) Target costing technique is considered one of the cost management techniques by private universities, and they are market oriented, as it is used in the stage of presenting the product from the product life cycle in order to enhance profitability and productivity and support the process of strategic decision-making;

3) Significant difference in the strength of links between the dimensions of the target costing technique and the dimensions of strengthening the competitive advantage in the Jordanian Private Universities;

4) Moreover, research findings indicate that the Jordanian Private Universities are connected to their environments, employees even seek answer to any problem they face from different sources inside the organizations, at the same time they are open to the external environment represented by the external community;

5) The leadership that supports target costing dimensions usage opportunities and training, continually learn, and safeguard the value system, is present in the researched organizations, but there is still a room for improvement.

\section{Recommendations}

The following are suggested as recommendations for the private universities:

1) Activate the role of the dimensions of target costing technique more.

2) Reduce the cost of the life cycle of university specialization and its design, taking care of all stages of the value chain of the world trade organization.

3) Open to the outside world and face economic and technological limitations, requiring more attention because of its impact on the sustainability of universities, their growth, and their survival.

4) Use target costing technique dimensions more to reduce the cost of the development of specializations and scientific programs as soon as possible to enable universities to enhance their competitive advantages.

5) Develop specialized administrative units in target costing aspects and entrusted with a broader and more comprehensive duties and functions than the accounting departments.

6) Train employees with courses to enhance their skills and experience in dimensions of target cost technique to meet the work requirements in the new environment.

7) To give attention to dimensions that have achieved excellence for existing universities, and to strengthen competitive advantages through the activation of target costing technique, as universities operating on it have a high competitive advantage. 
8) To consider an internal relations model as a path analysis models to detect the causal relationships within the system in Jordanian Private Universities.

9) To conduct further studies and field research on target costing technique in order to: reduce the universities' costs, increase profit, and increase competitive advantage.

\section{Limitations of the Study}

The study was limited to one of the cost management techniques, which is: target costing technique and measure its impact in enhancing the competitive advantage at the discretion of financial managers, planning and quality managers, heads of accounting departments and the costs sections in private universities because of the specificity of these universities with regard to the financial aspects. The study included only Jordanian Private Universities and did not include other Jordanian universities. This was mainly because of differences in capacities, administrative, financial and technical capacities, and objectives of private universities from public ones.

\section{Recommendations for future research}

Future research may try to activate the dimensions of target costing technique to achieve the competitive advantages and promote the universities in general and the Jordanian Private Universities in particular, as well as introducing variables in one model or more of direct and indirect relations according to the path analysis method (Path Analysis). Cooperation of governing universities activate the dimensions of target costing technique to achieve the competitive advantages and promote it atmosphere may also be an area for future investigation.

\section{References}

Abdel-Dayem., \& Safaa' Mohammed. (2001). Toward a proposed framework for the management target costing in the modern manufacturing environment. The scientific journal of the economy of Commerce, Ain Shams University, third edition, p: 470.

Al-Thahabi., JalelaEidan, Al-Ghabban., \& Tha'er Surrey. (2007). Target price as the basis for achieving target cost technique for economic units operating in the modern business environment. Journal of Economic and Administrative Sciences, 48(13).

Al-Matarneh., \& Ghassan Falah. (2008). Requirements and constraints of the application of the entrance to the target costing in Jordanian public shareholding industrial companies (field study). Damascus University Journal of Economics and legal, 24, 277-305.

Al-Qur'an., \& Ali Zakaria. (2007). The impact of flexible manufacturing on competitive advantage - a field study in the furniture industry companies operating in the city of King Abdullah II Industrial Estate - Sahab. unpublished Master Thesis, University of Al Al-Bayt.

Al-Skarna., \& Bilal Khalaf. (2005). Entrepreneurial strategies and their role in achieving competitive advantage and improve the performance of telecommunications companies in Jordan. unpublished $\mathrm{PhD}$ thesis, Faculty of Management high Studies and Finance, Amman Arab University for high Studies, Amman.

Al-Suboo., \& Suleiman SanadSabe'. (2000). Use of the ABC system and ABM methods for decision-making and evaluation the organization's performance, theoretical and practical study in the Middle East Complex for heavy Engineering and Electronics. Doctoral thesis in Accounting, Management and Economics Faculty, University of Baghdad.

Al-Zoubi, H. A. (2005). Information Systems Strategy. DarWael for Publishing and Distribution, Amman, Jordan.

Ansari, S., \& Bell J. (1997). Target Costing Core Group, Target Costing: The Next Frontier in Strategic Cost Management. USA: Mac Graw-Hill Inc.

Ansari, S., Bell, J., \& Swenson, Dan. (2006). A Template for Implementing Target Costing. Cost Management, 20(5), 21-27.

Cooper, R., \& Slagmuder. (2002). Target costing from New Product Development: Product level Target costing. Journal of Cost Management.

Cooper, R., \& Chew, W. B. (1996). Control tomorrow's costs through today's designs. Harvard Business Review, 88-97.

Darwish, Marwan Jum'a. (2007). Analysis of Islamic banking services quality, applied study on Islamic banks in Palestine. Third International Scientific Conference: Quality and Excellence in Business Organizations, University of Skikda. 
Ellram, L. (2006). The Implementation of Target Costing in the United States: Theory Versus Practice. Journal of Supply Chain Management: A Global Review of Purchasing and Supply, 42(1), 13-26.

Ergun, Ercan., \& Yilmaz, Cengiz. (2008). Organizational culture on firm effectiveness: An examination of relative effects of culture traits and the balanced culture hypothesis in an emerging economy. Journal of World Business Research, 43, 290-306. http://dx.doi.org/10.1016/j.jwb.2008.03.019

Evans., \& Collier. (2007). Operation Management an Integrated Goods and Services Approach. USA: Thomson South Western.

Ewert, R., \& Emst, C. (1999). Target costing, co-ordination and strategic cost management. European Accounting Review, 8(1), 23-49. http://dx.doi.org/10.1080/096381899336131

Fisher, J. (1995). Implementing target costing. Implementing target costing. Journal of Cost Management, 9(2), 50-59.

Fouda, Shawqi Al-Sayed. (2007). A proposed framework for integration between the target costing method and strategic cost analysis to reduce activities through the concept of the value chain. In Jamiat al-Iskandariyah., \& Kulliyat al-Tijarah (Eds.), Journal of the Faculty of Commerce for Scientific Research (pp. 209-235).

Hill Charles W. L., \& Jones, Gareth R. (2008). Strategic Management: an Integrated Approach. (8th ed.). Houghton Mifflin Company, USA.

Ibusuki, U., \& Kaminiski, P. (2007). Product development Process with focus on Value Engineering and Target-Costing: Case Study in an Automotive Company. International Journal of Production Economics, 105(2), 459-474. http://dx.doi.org/10.1016/j.ijpe.2005.08.009

Kato, Y. (1993). Target costing support systems: Lessons from leading Japanese companies. Management Accounting Research, 33-47. http://dx.doi.org/10.1006/mare.1993.1002

Kato, Y., Bőer, G., \& Chow, C.W. (1995). Target costing: an integrative management process. Cost Management, 9(1), 39-51.

Krajewski, Lee, J., \& Ritzman, Larry, P. (1999). Operation Management Strategy \& Analysis. (5th ed.). New York: Wesley Publishing Company.

Lee, J. Y. (1994). Use Target costing to improve your bottom-line. The CPA Journal, 64(1), 68-71.

Liu, Tsai-Lung. (2003). Organization Learning and Social Network Market Orientation: The Role of Resource-Based View Strategy Gaining in Dynamic, Capabilities Advantage. [Online] Available: http://www.hicbusiness.org/biz2003proceedings/Tsai-Lung\%20Liu.pdf

Monden, Y. (1995). Cost Reduction System: Target Costing and Kaizen Costing. Portland: Productivity Press.

Mufti, Mohammed Hassan Ali., \& Sheikh, Farid Omar. (2005). The effectiveness of the entrance to the application of target costing industrial enterprises: an exploratory study on a sample of industrial facilities in Jeddah. Journal of Faculty of Commerce for Scientific Research, Alexandria University, Egypt.

Pitts, R., \& David, L. (1999). Strategic Management Building and Sustaining Competitive Advantage. USA: West Publishing Company.

Rankin, Peter., Knezek, Gerald., Wallace, Suzan., \& Zhang, Showing. (2004). Scaling Methods. London: Lawrence Erlbaum Associates.

Robinson, F. (1999). Practical Guide to Target costing-Processes \& Techniques. London, UK: Kogan Page Limited.

Stevenson, William. J. (2007). Production/Operations Management. (8th ed.). Von Hoffmann Press.

Wahyuni, Sari., Ghauri, Pervez., \& Kartsen, Luchien. (2007). Managing Strategic Alliance relationships. Thunderbird International Business Review, 49(6), 672. http://dx.doi.org/10.1002/tie.20166

Zeenat, Mohammed Muharram. (1995). Use the entrance target costing to raise the efficiency of new product pricing decisions in the circumstances of contemporary dynamic environment. The scientific journal of the economy, Egypt, No. 1. 
Table 1. Coefficient Consistency of Target Costing and Competitive Advantage Fields in a Cronbach's Alpha and Hewitt Way

\begin{tabular}{|c|c|c|c|c|}
\hline Field & Item & $\begin{array}{l}\text { Number of } \\
\text { Items }\end{array}$ & $\begin{array}{l}\text { Cronbach's } \\
\text { Coefficient }\end{array}$ & $\begin{array}{l}\text { Hewitt(2) } \\
\text { Coefficient }\end{array}$ \\
\hline \multirow{6}{*}{$\begin{array}{c}\text { Target } \\
\text { Costing }\end{array}$} & 1. Target selling price leadership & 6 & 0.70 & 70.25 \\
\hline & 2. Focusing on students & 6 & 0.75 & 75.25 \\
\hline & 3. Using work teams and their developments & 6 & 0.70 & 70.20 \\
\hline & $\begin{array}{l}\text { 4. Reducing the cost of life cycle of university } \\
\text { specialization }\end{array}$ & 6 & 0.72 & 50.40 \\
\hline & $\begin{array}{l}\text { 5. Focusing on the design phase of university } \\
\text { specialization }\end{array}$ & 8 & 0.77 & 152.86 \\
\hline & 6. Taking care of all stages of value chain & 6 & 0.80 & 92.63 \\
\hline \multirow[t]{5}{*}{$\begin{array}{l}\text { Competitive } \\
\text { Advantage }\end{array}$} & $\begin{array}{l}\text { 1. Excellence and quality of university's } \\
\text { specializations }\end{array}$ & 5 & 0.70 & 70.25 \\
\hline & 2. University specialization cost & 8 & 0.75 & 50.75 \\
\hline & $\begin{array}{l}\text { 3. Innovation and creativity in academic } \\
\text { specialization }\end{array}$ & 7 & 0.70 & 60.50 \\
\hline & 4. Expansion of academic specialization & 5 & 0.74 & 70.25 \\
\hline & 5. Alliance & 5 & 0.76 & 50.26 \\
\hline
\end{tabular}

Table 2. Confirmatory Factor Analysis with Orthogonal Rotation Using Varimax Rotation to Each Field and its Dimension

\begin{tabular}{|c|c|c|c|c|c|c|c|c|c|c|c|}
\hline \multirow{2}{*}{$\begin{array}{c}\text { Paragraph } \\
\text { number }\end{array}$} & \multicolumn{6}{|c|}{ The First Field } & \multicolumn{5}{|c|}{ The Second Field } \\
\hline & 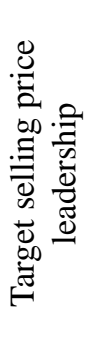 & 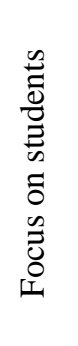 & 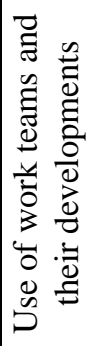 & 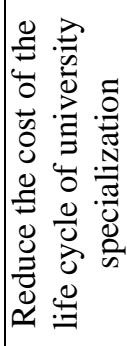 & 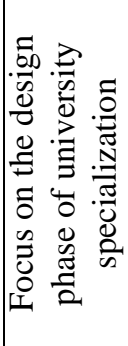 & 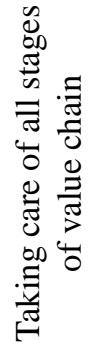 & 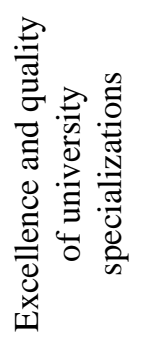 & 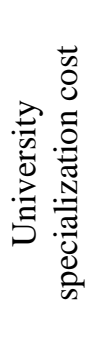 & 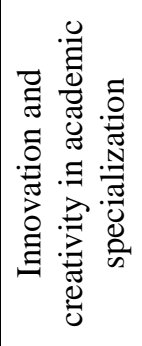 & 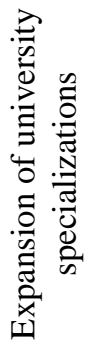 & $\begin{array}{l}\stackrel{\Xi}{\Xi} \\
\stackrel{\Xi}{\Xi} \\
\end{array}$ \\
\hline 1 & 0.66 & 0.63 & 0.71 & 0.51 & 0.71 & 0.80 & 0.63 & 0.79 & 0.75 & 0.65 & 0.70 \\
\hline 2 & 0.54 & 0.53 & 0.74 & 0.58 & 0.43 & 0.62 & 0.65 & 0.79 & 0.70 & 0.73 & 0.54 \\
\hline 3 & 0.62 & 0.68 & 0.70 & 0.75 & 0.78 & 0.70 & 0.73 & 0.81 & 0.74 & 0.63 & 0.66 \\
\hline 4 & 0.58 & 0.48 & 0.59 & 0.70 & 0.65 & 0.54 & 0.63 & 0.76 & 0.59 & 0.76 & 0.54 \\
\hline 5 & 0.61 & 0.60 & 0.49 & 0.74 & 0.63 & 0.66 & 0.76 & 0.51 & 0.68 & 0.62 & 0.51 \\
\hline 6 & 0.73 & 0.60 & 0.70 & 0.59 & 0.68 & 0.67 & & 0.76 & 0.70 & & \\
\hline 7 & & & & & 0.70 & & & 0.61 & 0.67 & & \\
\hline 8 & & & & & 0.67 & & & 0.73 & & & \\
\hline
\end{tabular}


Table 3. Corrected Correlation Coefficients between Statements of the Same Dimension after the Liberation

\begin{tabular}{|c|c|c|c|c|c|c|c|c|c|c|c|}
\hline \multirow{2}{*}{$\begin{array}{c}\text { Paragraph } \\
\text { number }\end{array}$} & \multicolumn{6}{|c|}{ The first field } & \multicolumn{5}{|c|}{ The second field } \\
\hline & 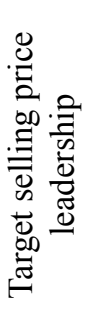 & 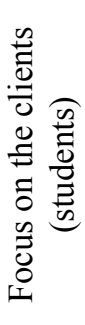 & 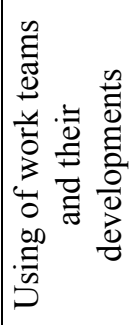 & 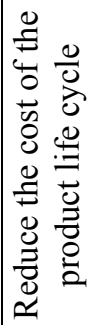 & 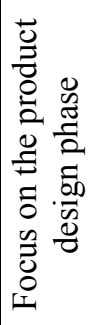 & 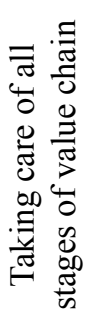 & 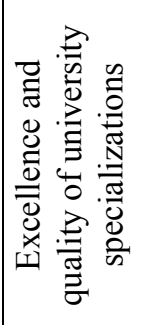 & 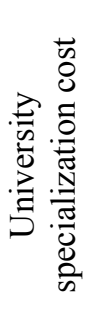 & 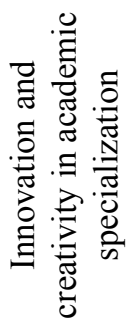 & 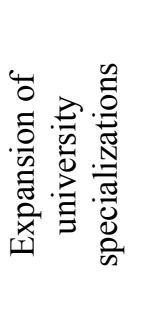 & 㽚 \\
\hline 1 & 0.31 & 0.33 & 0.80 & 0.47 & 0.47 & 0.92 & 0.75 & 0.37 & 0.54 & 0.53 & 0.67 \\
\hline 2 & 0.32 & 0.53 & 0.52 & 0.47 & 0.43 & 0.92 & 0.44 & 0.27 & 0.49 & 0.66 & 0.58 \\
\hline 3 & 0.37 & 0.49 & 0.58 & 0.38 & 0.55 & 0.93 & 0.41 & 0.38 & 0.74 & 0.35 & 0.74 \\
\hline 4 & 0.53 & 0.36 & 0.56 & 0.43 & 0.92 & 0.30 & 0.44 & 0.78 & 0.53 & 0.55 & 0.83 \\
\hline 5 & 0.35 & 0.49 & 0.50 & 0.39 & 0.95 & 0.44 & 0.58 & 0.52 & 0.38 & 0.80 & 0.33 \\
\hline 6 & 0.51 & 0.36 & 0.60 & 0.49 & 0.45 & 0.37 & & 0.28 & 0.45 & & \\
\hline 7 & & & & & 0.95 & & & 0.33 & 0.25 & & \\
\hline 8 & & & & & 0.53 & & & 0.52 & & & \\
\hline
\end{tabular}

Table 4. Characteristics of Individual Participants

\begin{tabular}{|c|c|c|}
\hline Variable & Categories & Percentage \\
\hline \multirow[t]{5}{*}{ Age } & $20-29$ & 24 \\
\hline & $30-39$ & 26 \\
\hline & $40-49$ & 35 \\
\hline & 50 and above & 15 \\
\hline & $20-29$ & 24 \\
\hline \multirow[t]{4}{*}{ Educational Level } & College Diploma or Less & 5 \\
\hline & Bachelor & 80 \\
\hline & Master & 15 \\
\hline & Doctorate & 0 \\
\hline \multirow{3}{*}{$\begin{array}{c}\text { University } \\
\text { Specialization }\end{array}$} & Business Administration & 64 \\
\hline & Accounting & 33 \\
\hline & Other Specializations & 3 \\
\hline \multirow{4}{*}{$\begin{array}{l}\text { Experience in the } \\
\text { Specialization Field }\end{array}$} & $1-5$ & 50 \\
\hline & $6-10$ & 30 \\
\hline & $11-15$ & 15 \\
\hline & 16 and above & 5 \\
\hline \multirow[t]{4}{*}{ Job Title } & Financial Manager & 52 \\
\hline & Planning and Quality Director & 28 \\
\hline & Head of Accounting Department & 28 \\
\hline & Head of Costs Division & 10 \\
\hline \multirow{3}{*}{$\begin{array}{c}\text { Administrative } \\
\text { Level }\end{array}$} & Senior Management & 54 \\
\hline & Middle Management & 41 \\
\hline & Lower Management & 5 \\
\hline
\end{tabular}


Table 5. Means and Standard Deviations for the Estimates of Sample's Members to the Level of Target Costing Technique dimensions under the Leadership of Target Selling Price

\begin{tabular}{|c|l|c|c|c|}
\hline Number & \multicolumn{1}{|c|}{ Paragraph } & $\begin{array}{c}\text { Arithmetic } \\
\text { Mean }\end{array}$ & $\begin{array}{c}\text { Standard } \\
\text { Deviation }\end{array}$ & Rank \\
\hline 1 & $\begin{array}{l}\text { Target Costing Technique contributes in expanding the number } \\
\text { of university's seats in the markets, according to competition } \\
\text { circumstances. }\end{array}$ & 4.28 & 0.45 & 1 \\
\hline 2 & $\begin{array}{l}\text { Target Costing Technique contributes in expanding the number } \\
\text { of seats in the university in the markets according to supply and } \\
\text { demand conditions. }\end{array}$ & 4.00 & 0.43 & 5 \\
\hline 3 & $\begin{array}{l}\text { Target Costing Technique helps identifying the target profit in } \\
\text { accordance with the financial requirements. }\end{array}$ & 4.18 & 0.58 & 3 \\
\hline 4 & $\begin{array}{l}\text { Target Costing Technique helps identifying the target profit in } \\
\text { accordance with the service of higher education conditions. }\end{array}$ & 4.09 & 0.52 & 4 \\
\hline 5 & $\begin{array}{l}\text { Target Costing Technique contributes in increasing your market } \\
\text { share in the different markets in which your university operates. }\end{array}$ & 4.27 & 0.62 & 2 \\
\hline 6 & $\begin{array}{l}\text { Target Costing Technique helps analyzing and understanding the } \\
\text { reasons and motivations for specific prices competitive in the } \\
\text { market and changes in the face of competitive threats and } \\
\text { challenges. }\end{array}$ & 4.00 & 0.43 & 5 \\
\hline & \multicolumn{1}{|c|}{ Overall Average } & 4.14 & 0.27 & \\
\hline
\end{tabular}

Table 6. Means and Standard Deviations for the Estimates of Sample's Members to the Level of dimensions of Target Costing Technique to Contribute in Focusing on Students

\begin{tabular}{|c|l|c|c|c|}
\hline Number & \multicolumn{1}{|c|}{ Paragraph } & $\begin{array}{c}\text { Arithmetic } \\
\text { mean }\end{array}$ & $\begin{array}{c}\text { Standard } \\
\text { Deviation }\end{array}$ & Rank \\
\hline 1 & $\begin{array}{l}\text { Target Costing Technique helps for a rapid response to } \\
\text { customers (students) requests in terms of quality of } \\
\text { educational services. }\end{array}$ & 4.00 & 0.43 & 4 \\
\hline 2 & $\begin{array}{l}\text { Target Costing Technique helps for a rapid respond to the } \\
\text { needs of students of university specializations. }\end{array}$ & 3.73 & 0.62 & 6 \\
\hline 3 & $\begin{array}{l}\text { Target Costing Technique contributes in focusing on } \\
\text { achieving the fulfillment of the expectations of students } \\
\text { and to be compatible with. }\end{array}$ & 4.00 & 0.61 & 4 \\
\hline 4 & $\begin{array}{l}\text { Target Costing Technique contributes in focusing on } \\
\text { achieving excellence on the students' expectations. }\end{array}$ & 4.36 & 0.65 & 1 \\
\hline 5 & $\begin{array}{l}\text { Target Costing Technique helps to respond to the } \\
\text { renewable needs of students. }\end{array}$ & 4.27 & 0.62 & 2 \\
\hline 6 & $\begin{array}{l}\text { Target Costing Technique helps on offering new specialties } \\
\text { from period to period. }\end{array}$ & 4.09 & 0.29 & 3 \\
\hline \multicolumn{1}{|l|}{ Overall Average } & 4.08 & 0.37 & \\
\hline
\end{tabular}


Table 7. Means and Standard Deviations for the Members' Sample Estimations of the Target Cost Technique dimensions Related to Use Work Teams and their Developments

\begin{tabular}{|c|l|c|c|c|}
\hline Number & \multicolumn{1}{|c|}{ Paragraph } & $\begin{array}{c}\text { Arithmetic } \\
\text { Mean }\end{array}$ & $\begin{array}{c}\text { Standard } \\
\text { Deviation }\end{array}$ & Rank \\
\hline 1 & $\begin{array}{l}\text { Target Cost Technique contributes in the development of } \\
\text { a new university specialization through a specialized team } \\
\text { work. }\end{array}$ & 4.36 & 0.65 & 1 \\
\hline 2 & $\begin{array}{l}\text { Target Cost Technique contributes in the development of } \\
\text { a new university specialization through an experienced } \\
\text { team work. }\end{array}$ & 3.82 & 0.58 & 2 \\
\hline 3 & $\begin{array}{l}\text { Target Cost Technique contributes in the development of } \\
\text { a new university specialization through a variable } \\
\text { functional work team (academic, administrative, financial } \\
\text { and technical departments) }\end{array}$ & 3.73 & 0.45 & 4 \\
\hline 4 & $\begin{array}{l}\text { Target Cost Technique helps to develop a new scientific } \\
\text { specialization by involving members of the labor market. }\end{array}$ & 3.45 & 0.66 & 6 \\
\hline 5 & $\begin{array}{l}\text { Target Cost Technique contributes in the development of } \\
\text { a new scientific specialization by involving graduates } \\
\text { student members. }\end{array}$ & 3.82 & 0.72 & 2 \\
\hline 6 & $\begin{array}{l}\text { Target Cost Technique contributes in the development of } \\
\text { a new scientific specialization to involve members of } \\
\text { their parents. }\end{array}$ & 3.73 & 0.62 & 4 \\
\hline
\end{tabular}

Table 8. Means and Standard Deviations for the Members' Sample Estimations of the Target Cost Technique dimensions Related to Decreasing the Cost of the Life Cycle of University Specialization

\begin{tabular}{|c|l|c|c|c|}
\hline Number & \multicolumn{1}{|c|}{ Paragraph } & $\begin{array}{c}\text { Arithmetic } \\
\text { Mean }\end{array}$ & $\begin{array}{c}\text { Standard } \\
\text { Deviation }\end{array}$ & Rank \\
\hline 1 & $\begin{array}{l}\text { Target Cost Technique contributes in fading out the cost of } \\
\text { developing a new university specialization after a time of } \\
\text { adopting it. }\end{array}$ & 3.27 & 0.45 & 1 \\
\hline 2 & $\begin{array}{l}\text { Target Cost Technique helps to adapt the cost of the } \\
\text { development of a new university specialization with the } \\
\text { numbers of registered university students to achieve a } \\
\text { reasonable margin profit within a reasonable time. }\end{array}$ & 2.91 & 0.68 & 3 \\
\hline 3 & $\begin{array}{l}\text { Target Cost Technique contributes in making the loss after a } \\
\text { reasonable time of developing a new university specialization } \\
\text { is null as a result of the reluctance of students on registration } \\
\text { in it. }\end{array}$ & 2.82 & 0.58 & 4 \\
\hline 4 & $\begin{array}{l}\text { Target Cost Technique helps the universities to consider all } \\
\text { cost elements related to possessing educational services } \\
\text { through all stages of their life cycle. }\end{array}$ & 3.00 & 0.75 & 2 \\
\hline 5 & $\begin{array}{l}\text { Target Cost Technique helps the university to study the costs } \\
\text { of disposal of the existing university specializations at the end } \\
\text { of their life cycle. }\end{array}$ & 2.73 & 0.76 & 6 \\
\hline 6 & $\begin{array}{l}\text { Target Cost Technique helps the university to study the costs } \\
\text { of disposal of the developing new specializations at the end of } \\
\text { their life cycle. }\end{array}$ & 2.82 & 0.58 & 4 \\
\hline
\end{tabular}


Table 9. Means and Standard Deviations for the Members' Sample Estimations of the Target Cost Technique dimensions Related to Focusing on the University Specialization Design Stage

\begin{tabular}{|c|l|c|c|c|}
\hline Number & \multicolumn{1}{|c|}{ Paragraph } & $\begin{array}{c}\text { Arithmetic } \\
\text { Mean }\end{array}$ & $\begin{array}{c}\text { Standard } \\
\text { Deviation }\end{array}$ & Rank \\
\hline 1 & $\begin{array}{l}\text { Target Cost Technique contributes in accelerating the } \\
\text { response rate to the requirements of the student in different } \\
\text { markets. }\end{array}$ & 3.18 & 0.39 & 2 \\
\hline 2 & $\begin{array}{l}\text { Target Cost Technique contributes in reduction of the time } \\
\text { length between the developments of university } \\
\text { specialization and delivering it to the student in different } \\
\text { markets. }\end{array}$ & 3.27 & 0.87 & 1 \\
\hline 3 & $\begin{array}{l}\text { Target Cost Technique helps to add new features to } \\
\text { scientific specialization to response to the requirements of } \\
\text { students in different markets. }\end{array}$ & 2.64 & 0.65 & 8 \\
\hline 4 & $\begin{array}{l}\text { Target Costing Technique helps to improve the quality of } \\
\text { university specializations. }\end{array}$ & 2.91 & 0.80 & 6 \\
\hline 5 & $\begin{array}{l}\text { Target Costing Technique helps to increase the number of } \\
\text { benefits earned by the student in different markets. }\end{array}$ & 3.00 & 0.43 & 4 \\
\hline 6 & $\begin{array}{l}\text { Target Costing Technique helps to reduce the number of } \\
\text { students' complaints in different markets. }\end{array}$ & 3.00 & 0.75 & 4 \\
\hline 7 & $\begin{array}{l}\text { Target Costing Technique helps to maximize the value that } \\
\text { accrues to students from specialization university in } \\
\text { different markets. }\end{array}$ & 3.09 & 0.52 & 3 \\
\hline 8 & $\begin{array}{l}\text { Target Costing Technique contributes in modifying the } \\
\text { university specializations to suit the requirements and } \\
\text { needs of their markets. }\end{array}$ & 2.82 & 0.72 & 7 \\
\hline
\end{tabular}

Table 10. Means and Standard Deviations for the Members' Sample Estimations of the Target Cost Technique Dimensions Related to Taking Care of all Stages of the Value Chain

\begin{tabular}{|c|l|c|c|c|}
\hline Number & \multicolumn{1}{|c|}{ Paragraph } & $\begin{array}{c}\text { Arithmetic } \\
\text { Mean }\end{array}$ & $\begin{array}{c}\text { Standard } \\
\text { deviation }\end{array}$ & Rank \\
\hline 1 & $\begin{array}{l}\text { Target Costing Technique contributes in involving the ally } \\
\text { with the university specializations' requirements. }\end{array}$ & 3.18 & 0.39 & 2 \\
\hline 2 & $\begin{array}{l}\text { Target Costing Technique contributes in involving the ally } \\
\text { in marketing a particular specialty for your university. }\end{array}$ & 3.10 & 0.68 & 3 \\
\hline 3 & $\begin{array}{l}\text { Target Costing Technique helps the ally to take into } \\
\text { account the need and the desire of your university in the } \\
\text { demand for your specialization. }\end{array}$ & 2.91 & 0.91 & 5 \\
\hline 4 & $\begin{array}{l}\text { Target Costing Technique contributes in participating in } \\
\text { providing the ally at your university with necessary market } \\
\text { information. }\end{array}$ & 2.90 & 0.80 & 6 \\
\hline 5 & $\begin{array}{l}\text { Target Costing Technique contributes in involving the ally } \\
\text { in efforts to reduce costs through the development of the } \\
\text { spirit of cooperation and understanding. }\end{array}$ & 3.09 & 0.80 & 4 \\
\hline 6 & $\begin{array}{l}\text { Target Costing Technique System accredited in your } \\
\text { university depend on building a mutual relationships of } \\
\text { benefits with the ally on the long-term. }\end{array}$ & 3.27 & 0.87 & 1 \\
\hline \multicolumn{1}{|l}{ Overall Average } & 3.08 & 0.54 & \\
\hline
\end{tabular}


Table 11. Means and Standard Deviations for the Members' sample Estimation on the dimensions of enhancing the Competitive Advantage with its Five Dimensions

\begin{tabular}{|c|c|c|c|c|}
\hline Number & Excellence and Quality of University's Specializations & Mean & \begin{tabular}{|c|} 
Standard \\
Deviation
\end{tabular} & Rank \\
\hline 1 & $\begin{array}{l}\text { Your university adopts a clear policy and documented for } \\
\text { excellence and quality. }\end{array}$ & 3.55 & 0.50 & 4 \\
\hline 2 & $\begin{array}{l}\text { Your university is seeking to reduce saturated programs in our } \\
\text { faculty programs consistently. }\end{array}$ & 3.43 & 0.65 & 3 \\
\hline 3 & $\begin{array}{l}\text { Improving the quality awareness of the employees at our } \\
\text { university constantly. }\end{array}$ & 3.64 & 0.49 & 2 \\
\hline 4 & $\begin{array}{l}\text { Our university seeks to make the specification of teaching } \\
\text { programs matching with the requirements of the local market } \\
\text { and the Arab world. }\end{array}$ & 3.73 & 0.45 & 1 \\
\hline 5 & $\begin{array}{l}\text { Our university is working on the design of teaching programs } \\
\text { properly to achieve the best possible level of developed } \\
\text { programs. }\end{array}$ & 3.54 & 0.50 & 5 \\
\hline & Overall Average & 3.62 & 0.22 & \\
\hline \multicolumn{5}{|c|}{ University Specialization Cost } \\
\hline 1 & $\begin{array}{l}\text { Our university is seeking to reduce the rate of presenting } \\
\text { university specializations which is unprofitable in the short and } \\
\text { long-term. }\end{array}$ & 3.38 & 0.49 & 2 \\
\hline 2 & $\begin{array}{l}\text { Our university interested in improving the average of daily } \\
\text { performance for the faculty members. }\end{array}$ & 3.45 & 0.50 & 1 \\
\hline 3 & $\begin{array}{l}\text { Our university is seeking to improve the failure rate of } \\
\text { occupancy (teaching rooms, laboratories and library). }\end{array}$ & 3.09 & 0.29 & 7 \\
\hline 4 & $\begin{array}{l}\text { Our university interested in improving the efficient use of } \\
\text { specialist and administrative human factors. }\end{array}$ & 3.18 & 0.39 & 6 \\
\hline 5 & $\begin{array}{l}\text { At our university the interest of improving the efficiency of the } \\
\text { use of technology. }\end{array}$ & 3.373 .37 & 0.49 & 3 \\
\hline 6 & Our university is seeking to reduce the average cost of student. & 3.36 & 0.65 & 4 \\
\hline 7 & $\begin{array}{l}\text { Our university is seeking to reduce the cost ratio of students } \\
\text { according to total costs. }\end{array}$ & 3.18 & 0.39 & 6 \\
\hline 8 & $\begin{array}{l}\text { Our university is seeking to improve the systems design of its } \\
\text { activities that based on computer. }\end{array}$ & 3.36 & 0.49 & 4 \\
\hline & Overall Average & 3.30 & 0.16 & \\
\hline \multicolumn{5}{|c|}{ Innovation and Creativity in Academic Specializations } \\
\hline 1 & $\begin{array}{l}\text { Our university is presenting new academic specializations in } \\
\text { different markets. }\end{array}$ & 3.64 & 0.49 & 1 \\
\hline 2 & $\begin{array}{l}\text { Our university is working to increase management's ability to } \\
\text { change in university specializations to correspond with the } \\
\text { different markets. }\end{array}$ & 3.36 & 0.49 & 3 \\
\hline 3 & $\begin{array}{l}\text { Our university is working to increase the viability of working } \\
\text { for change and dealing with new educational technologies. }\end{array}$ & 3.18 & 0.58 & 6 \\
\hline 4 & $\begin{array}{l}\text { Our university is working to improve our ability to introduce } \\
\text { advanced technology in teaching process. }\end{array}$ & 3.09 & 0.52 & 7 \\
\hline 5 & $\begin{array}{l}\text { Our university improves the rate improvements that we make } \\
\text { to the quality of educational services. }\end{array}$ & 3.27 & 0.45 & 4 \\
\hline 6 & $\begin{array}{l}\text { Our university improves our ability to use available } \\
\text { technology. }\end{array}$ & 3.55 & 0.50 & 2 \\
\hline 7 & Our university has the ability to identify appropriate markets. & 3.27 & 0.45 & 4 \\
\hline & Overall Average & 3.34 & 0.22 & \\
\hline
\end{tabular}




\begin{tabular}{|c|c|c|c|c|}
\hline \multicolumn{5}{|c|}{ Expansion of Academic Specialization } \\
\hline 1 & Our University has achieved an increase in profitability. & 3.55 & 0.50 & 4 \\
\hline 2 & Our University has achieved an increase in market share. & 3.45 & 0.66 & 5 \\
\hline 3 & $\begin{array}{l}\text { Our University has achieved an increase in the number of local } \\
\text { students. }\end{array}$ & 3.64 & 0.49 & 3 \\
\hline 4 & $\begin{array}{l}\text { Our University has achieved an increase in the number of Arab } \\
\text { and foreign students. }\end{array}$ & 3.91 & 0.29 & 1 \\
\hline 5 & Our university penetrated new markets. & 3.90 & 0.52 & 2 \\
\hline & Overall Average & 3.69 & 0.20 & \\
\hline \multicolumn{5}{|c|}{ Alliance } \\
\hline 1 & $\begin{array}{l}\text { Our university alliance with Arab and foreign universities } \\
\text { contributed in reducing the costs of research and development. }\end{array}$ & 3.27 & 0.45 & 5 \\
\hline 2 & $\begin{array}{l}\text { Our university alliance with Arab and foreign universities } \\
\text { contributed in reducing the wages and salary of faculty } \\
\text { members in the teaching process. }\end{array}$ & 3.55 & 0.66 & 3 \\
\hline 3 & $\begin{array}{l}\text { Our university alliance with Arab and foreign universities } \\
\text { contributed in reducing the average cost per student. }\end{array}$ & 3.56 & 0.66 & 2 \\
\hline 4 & $\begin{array}{l}\text { Our university alliance with Arab and foreign universities } \\
\text { contributed in reducing the cost of marketing programs } \\
\text { teaching in foreign markets. }\end{array}$ & 3.54 & 0.66 & 4 \\
\hline 5 & $\begin{array}{l}\text { Our university alliance with Arab and foreign universities } \\
\text { contributed in reducing their administrative costs. }\end{array}$ & 3.91 & 0.29 & 1 \\
\hline & Overall Average & 3.56 & 0.34 & \\
\hline
\end{tabular}

Table 12. Partial Correlation Coefficients between the Dimensions of Target Costing Technique and Dimensions of Competitive Advantage Promotion in the Study Tool and Overall Link.

\begin{tabular}{|l|c|c|c|c|c|}
\hline \multicolumn{1}{|c|}{ Dimensions } & $\begin{array}{l}\text { Excellence and } \\
\text { Quality of } \\
\text { University's } \\
\text { Specializations }\end{array}$ & $\begin{array}{l}\text { University } \\
\text { Specialization } \\
\text { Cost }\end{array}$ & $\begin{array}{l}\text { Innovation and } \\
\text { Creativity in } \\
\text { Universities } \\
\text { Specializations }\end{array}$ & $\begin{array}{l}\text { Expansion in } \\
\text { University's } \\
\text { Specializations }\end{array}$ & Alliance \\
\hline Target Price leadership & 0.17 & 0.06 & $0.36^{*}$ & 0.18 & $0.38^{* *}$ \\
\hline Focus on students & 0.17 & $0.35^{*}$ & 0.13 & $0.56^{* *}$ & $0.37^{* *}$ \\
\hline $\begin{array}{l}\text { Using team works and } \\
\text { their development }\end{array}$ & 0.04 & $0.42^{* *}$ & $0.32^{*}$ & 0.20 & 0.05 \\
\hline $\begin{array}{l}\text { Reduce the cost of the } \\
\text { life cycle of academic } \\
\text { specialization }\end{array}$ & 0.13 & $0.50^{* *}$ & 0.08 & $0.55^{* *}$ & $0.41^{* *}$ \\
\hline $\begin{array}{l}\text { Focus on the design of } \\
\text { university specialization }\end{array}$ & 0.001 & 0.06 & $0.32 *$ & $0.34 * *$ & 0.24 \\
\hline $\begin{array}{l}\text { Taking care of all stages } \\
\text { of the value chain }\end{array}$ & $0.35^{*}$ & 0.00 & $0.31^{*}$ & $0.39 * *$ & 0.18 \\
\hline
\end{tabular}

* Correlation coefficient is statistically significant at the level of $(0.05)$

* * Coefficient statistically significant at the level of $(0.01)$

* Overall correlation coefficient between the dimensions of total target costing technique and enhance the competitive advantage $=0.57$. 
Table 13. Regression Analysis of the Target Costing Dimensions for each Factor of Strengthening the Competitive Advantage

\begin{tabular}{|c|c|c|c|c|c|c|c|c|c|c|c|c|c|c|}
\hline \multirow[t]{2}{*}{ Factor } & \multicolumn{2}{|c|}{$\begin{array}{l}\text { Excellence and } \\
\text { Quality of } \\
\text { University's } \\
\text { Specializations }\end{array}$} & \multicolumn{3}{|c|}{$\begin{array}{c}\text { University } \\
\text { Specialization } \\
\text { Cost }\end{array}$} & \multicolumn{3}{|c|}{$\begin{array}{l}\text { Innovation and } \\
\text { Creativity in } \\
\text { Universities } \\
\text { Specializations }\end{array}$} & \multicolumn{2}{|c|}{$\begin{array}{c}\text { Expansion in } \\
\text { University’s } \\
\text { Specializations }\end{array}$} & \multicolumn{2}{|c|}{ Alliance } & \multicolumn{2}{|c|}{$\begin{array}{c}\text { (Total } \\
\text { (competitive } \\
\text { advantage) }\end{array}$} \\
\hline & $\beta$ & Sign. & $\beta$ & $\mathrm{S}$ & & $\beta$ & S & & $\beta$ & Sig. & $\beta$ & Sig. & $\beta$ & Sig. \\
\hline $\begin{array}{l}\text { Target price } \\
\text { leadership }\end{array}$ & 0.62 & 0.00 & 0.24 & & & 0.60 & & & 0.17 & 0.22 & 0.29 & 0.09 & 0.65 & 0.01 \\
\hline Focus on students & 0.73 & 0.00 & 0.70 & & & 0.89 & & & 0.40 & 0.02 & 0.31 & 0.12 & 0.89 & 0.00 \\
\hline $\begin{array}{l}\text { Using work teams } \\
\text { and their } \\
\text { development }\end{array}$ & 0.04 & 0.73 & 0.46 & & & 0.25 & & & -0.30 & 0.05 & 0.22 & 0.22 & 025 & 0.06 \\
\hline $\begin{array}{l}\text { Reduce the cost of } \\
\text { the life cycle of } \\
\text { academic } \\
\text { specialization }\end{array}$ & 0.25 & 0.05 & 0.45 & & & 0.13 & & & 0.68 & 0.00 & 0.13 & 0.53 & 0.44 & 00.00 \\
\hline $\begin{array}{l}\text { Focus on the } \\
\text { design phase of } \\
\text { university } \\
\text { specialization }\end{array}$ & 0.56 & 0.00 & -0.05 & & & -0.19 & & & -0.53 & 0.02 & 0.02 & 0.93 & $0.06-$ & 0.77 \\
\hline $\begin{array}{l}\text { Taking care of all } \\
\text { stages of the value } \\
\text { chain }\end{array}$ & -1.34 & 0.00 & -0.42 & & & -0.73 & & & 0.25 & 0.21 & 0.01 & 0.97 & -0.64 & 0.00 \\
\hline \multicolumn{15}{|c|}{$\begin{array}{l}\text { Regression equations derived from the gradual regression (Stepwise) and the proportion of interpreter } \mathrm{R}^{2} \\
\text { variance virtual and (amended) }\end{array}$} \\
\hline 1 & \multicolumn{2}{|c|}{$\mathrm{R}^{2}=(0.20)$} & \multicolumn{2}{|c|}{$R=(0.44)$} & \multicolumn{3}{|c|}{$F=(10.60)$} & \multicolumn{3}{|c|}{ Constant (4.21) } & & & & \\
\hline 2 & \multicolumn{2}{|c|}{$\mathrm{R}^{2}=(0.37)$} & \multicolumn{2}{|c|}{$\mathrm{R}=(0.61)$} & \multicolumn{3}{|c|}{$F=(12.15)$} & \multicolumn{3}{|c|}{ Constant (3.75) } & & & & \\
\hline 3 & \multicolumn{2}{|c|}{$\mathrm{R}^{2}=(0.51)$} & \multicolumn{2}{|c|}{$R=(0.72)$} & \multicolumn{3}{|c|}{$\mathrm{F}=(14.45)$} & \multicolumn{3}{|c|}{ Constant (4.72) } & & & & \\
\hline
\end{tabular}

